\title{
アセファート加用による合成ピレスロイド剤の ミカンハダニに対する効果の増大
}

関 道生 (北興化学工業株式会社)

\begin{abstract}
Enhancement of activity of synthetic pyrethroids against citrus red mite by mixing with acephate. Michio SEKI (Hokko Chemical Industry Co., Chuohku, Tokyo 103)
\end{abstract}

合成ピレスロイド郕（以下合ピレ骩と称する）㹥，か んきつの重要害虫であるチャノキイロアザミウマやミカ ン八モグリガなどにすぐれた効果を示すが，反面八ダニ のリサージェンス現象を惹起することが活用場面での障 害となっている。著者は1983年以来，ミカン八ダ二を対 象として行ってきた一連の試験の結果から，合ピレ剤で も殺ダ二活性を持つものの中のあるものはリサージェン ス現象惹起の䜿念が少なく，またアセファートを加用す ることによって殺ダニ刻として使用できるほどの効果が 期待できることを知った。ここでは1984年〜1986年に得 られた試験の結果を報告する。

\section{材料および方法}

試験は佐賀県小城町晴気の八朔園（試験開始当時の樹 齢 8 年) で 1 区に 3〜 4樹を供試して行なった。薬剤は 動力噴霧機を使用し，薬液が葉から滴りおちる程度に十 分量散布した。散布前及び散布後一定間隔で 1 樹から莱 20枚を任意抽出し，葉上の雌成虫数を計測した。供試し た合ピレ剤は, フェンプロパトリン $10 \%$ 乳剤, フルバリ ネート $20 \%$ 水和剤，フリシトリネート $5 \%$ 水和剤，フェ ンバレレート $10 \%$ 乳戍, ペルメトリン $20 \%$ 乳剤, エトフ エンプロックス $20 \%$ 水和剤で，加用薬骫としは，アセフ エート $50 \%$ 水和剤のほかオキシデプロホス $45 \%$ 乳戍, プ ロチオホス $45 \%$ 乳㓲，イソキサチオン $50 \%$ 乳剤, ジメ卜 エート $43 \%$ 乳骫，メチダチオン $40 \%$ 乳㓲などの有機リン
系殺虫戍を供試した。

\section{結果および考慮}

各種合ピレ郕を単用で散布した場合のミカンハダニに 対する効果は第 1 表のとおりで，散布40日後においてフ エンプロパトリン以外の合ピレ剤散布区はいずれもリ サージェンスとみなされる程度に密度が増加した。散布 前の密度が低かったこともあって，フェンプロパトリン とフルバリネートはともに散布後30日まではハダ二の密 度を顕著におさえ，さらにフェンプロパトリンの場合散 布40日後においても無処理区の密度を下回った。すなわ ちフェンプロパトリンは殺ダニ雯のヘキンチアゾクスに はおよばないまでも，合ピレ凨の中では最も殺ダニ活性 が高いものとみなされ、この結果は行徳ら（1988）の結 果に一致した。

古橋・西野（1984）はかんきつに寄生しているミカン ハダニに対して数種の合ピレ棛を散布したところ，散布 37日後に異常に密度が高くなることを認めたが，フルシ トリネートとある種の有機リン化合物の混合骩である CYT-335水和剤だけはそれほど密度が上昇しなかった ことを報告している。その後この有機リン化合物はアセ フェートであることが公表された（日本植物防除協会編 カンキツ農薬連絡試験成績第21集1984）ことから著者は アセフェートの効果に注目し，各種の合ピレ剂にアセフ エートを加用してミカンハダニに対する効果をみる試験

第 1 表 合成ピレスロイド糊のミカンハダニに対する効果 1985年6月15日散布

\begin{tabular}{|c|c|c|c|c|c|c|}
\hline $\begin{array}{l}\text { 薬版の種類と } \\
\text { 散布濃度 } \mathrm{ppm}\end{array}$ & 散布前 & $\begin{array}{c}1 \\
1 \text { 日後 }\end{array}$ & $\begin{array}{c}\text { 当り } \\
14 \text { 日後 }\end{array}$ & $\begin{array}{c}\text { 雌 成 } \\
22 \text { 日後 }\end{array}$ & $\begin{array}{l}\text { 数 } \\
30 \text { 日後 }\end{array}$ & 40日後 \\
\hline フェンプロパトリン 50 & 0.4 & 0.1 & 0 & 0.2 & 0.7 & 4.2 \\
\hline フルハリネート 100 & 0.3 & 0.1 & 0 & 0.5 & 0.4 & 8.6 \\
\hline フルシトリネート 50 & 0.5 & 0.1 & 0.1 & 1.0 & 2.4 & 8.6 \\
\hline フェンバレレート 50 & 0.4 & 0.2 & 0.4 & 1.3 & 2.8 & 9.8 \\
\hline ヘキシチアソクス 50 & 0.4 & 0.1 & 0 & 0.1 & 0.3 & 1.6 \\
\hline 無 処 & 0.3 & 0.4 & 1.7 & 3.7 & 5.1 & 6.1 \\
\hline
\end{tabular}




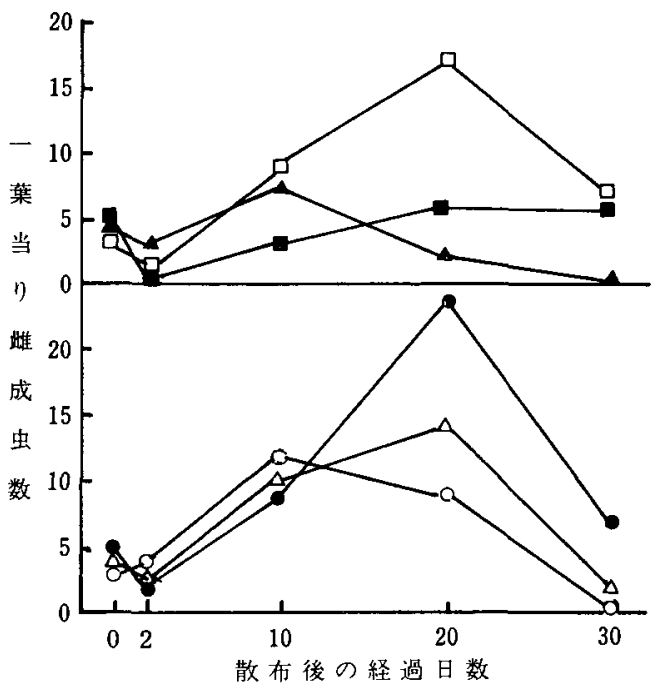

第 1 図エトフェンプロックス $(80 \mathrm{ppm})$ ，ペルメトリン $(100 \mathrm{ppm})$ にアセフェート(300ppm)を加用，1984年 7 月14日散布

ロ：ペルメトリン単用 $\mathbf{a}$ : ペルメトリントアセフェート

・: 無処理 ○：エトフェンプロックス単用

・ : エトフェンプロックス十アセフェート

$\triangle: ア セ フ ェ ー ト$ 単用

を行なった。第 1 図はエトフェンプロックスとペルメト リンのそれぞれにアセフェートを加用した場合の效果で あるが, 殺ダ二活性のないエトフェンプロックスはアセ フェートの加用効果が認められず，八ダ二の密度はエト フェンプロックスの単用以上に上昇した。一方若印殺 ダ二活性を保有するペルメトリンではアせフェートの加 用効果が認められた。フェンバレレートの場合も第 2 図 のように傾向はペルメトリンと同様であるが，アセフ エートの加用效果を認め得るという程度であって八ダニ 防除が可能といえるほどのものではない。合ピレ郕の中 でも比較的殺ダ二活性が高いとされているフェンプロパ トリン，フルバリネート，フルシトリネートにアセフ エートを加用した試験の成績が第 3 図でいずれも顕著な 加用効果が認められた。散布20日後のハダ二密度でみる と笚用とアセフェート加用との差が大きいのはフルシト リネートであるが, 散布30日後における八ダ二密度から みて期待されるミカンハダニ防除効果はフェンプロパト リンとアセフェートの混用が最大とみなされる。以上の ようにミカンハダニに対する合ピレ剮の效果がアセフ ェートの加用によって増大するのは，アセフェート自体 はミカンハダニにほとんど効果がない(第1図)こと， 殺ダ二活性の高い合ピレ剤ほど加用効果が高いことから 雨者の共力作用によるものと思われる。

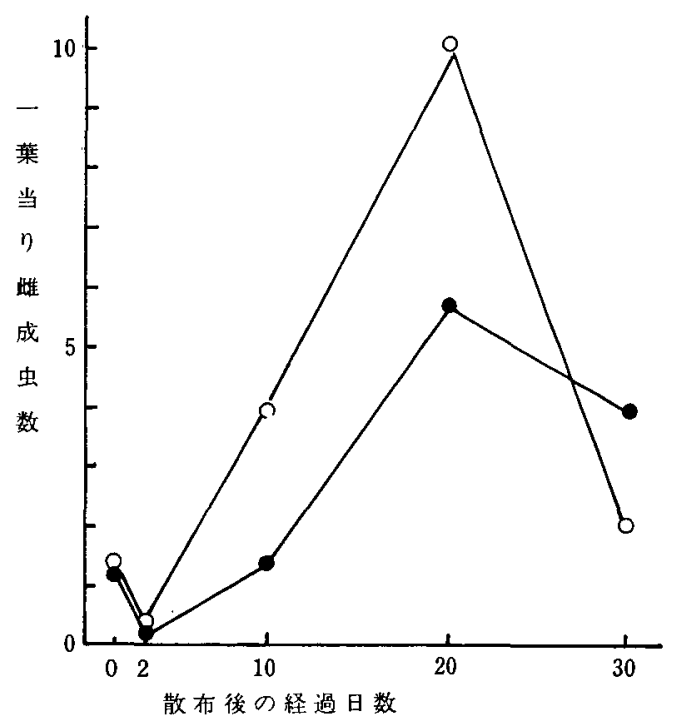

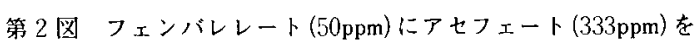
加用，1984年 7 月14日散布

ミ:フェンバレレート単用

・フフメンバレレート十アセフェート

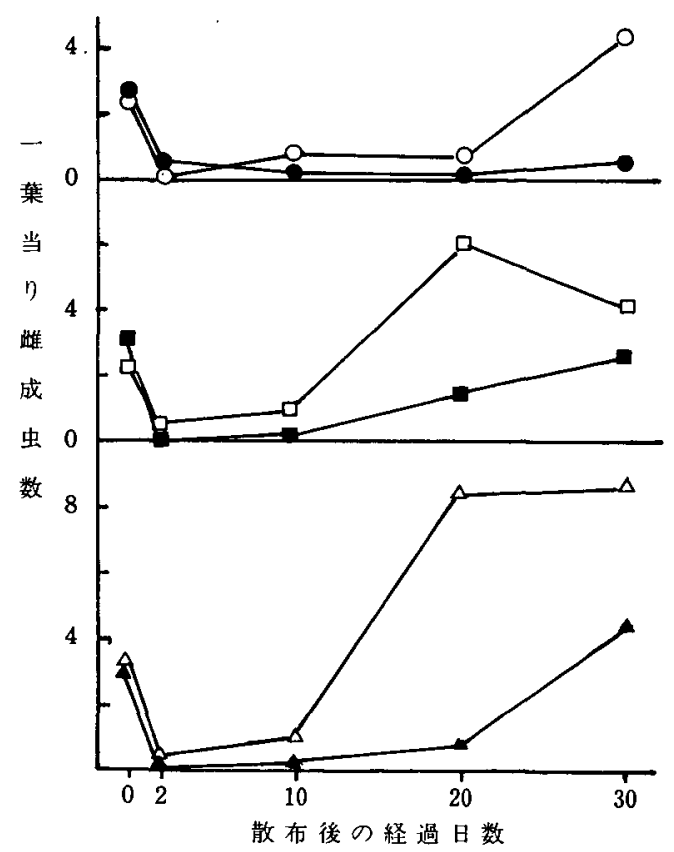

第3図フェンプロパトリン $(50 \mathrm{ppm})$ ，フルバリネート $(10 \mathrm{ppm})$,

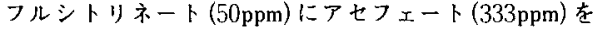
加用, 1985年 7 月14日散布

0：フェンロパトリン単用 ロ：フルバリネート単用 $\triangle$ : フルシトリネート単用

・：フェンプロパトリントアセフェート

ロ:フルパリート十フセフェート

ム：フルシトリネート十アセフェート 
第 2 表 フルパリネートに各種有機リン系殺虫剤を加用した場合のミカンハダニに 対する効果1986年 7 月25日散布

\begin{tabular}{|c|c|c|c|c|c|}
\hline $\begin{array}{l}\text { 加用薬剂の種類と } \\
\text { 散布濃度 ppm }\end{array}$ & 散布前 & $\begin{array}{l}1 \text { 葉 } \\
2 \text { 日後 }\end{array}$ & $\begin{array}{l}り \text { 雌 } \\
10 \text { 日後 }\end{array}$ & $\begin{array}{l}\text { 虫数 } \\
20 日 \text { 後 }\end{array}$ & 30日後 \\
\hline フルバリネート単用 100 & 2.9 & 0.1 & 0.4 & 0.8 & 9.9 \\
\hline $\boldsymbol{T}>x-ト 500$ & 2.9 & 0.1 & 0.1 & 0.1 & 1.2 \\
\hline オキシデプロホス 450 & 3.0 & 0.1 & 0.2 & 0.3 & 5.1 \\
\hline プロチオホス 450 & 2.5 & 0.1 & 0.2 & 0.2 & 5.0 \\
\hline イソキサチオン 500 & 2.3 & 0.1 & 0.2 & 0.2 & 5.0 \\
\hline メチダチオン 400 & 2.3 & 0.1 & 0.1 & 0.2 & 5.9 \\
\hline$\because \times ト I-卜 430$ & 2.3 & 0.1 & 0.7 & 1.5 & 8.7 \\
\hline 無 処 理 & 2.1 & 1.2 & 2.4 & 1.2 & 3.2 \\
\hline
\end{tabular}

第 3 表 ミカンハダニに対するアセフェートの濃度別加用効果, フェンプロパトリ 及びフルバリネートに加用した場合１986年6月8日散布

\begin{tabular}{|c|c|c|c|c|c|c|c|}
\hline $\begin{array}{l}\text { 薬剂の種類と } \\
\text { 散布濃度 ppm }\end{array}$ & $\begin{array}{l}\text { 加用アセフェー } \\
\text { トの濃度ppm }\end{array}$ & 散 布 前 & & $\begin{array}{c}\text { 䖟 当 } \\
\text { 日 後 } 9\end{array}$ & り 雌 & $\begin{array}{l}\text { 戊 虫 数 } \\
19 \text { 日後 }\end{array}$ & 33 日後 \\
\hline \multirow{4}{*}{$\begin{array}{l}\text { フェンプロ } \\
\text { パトリン } \\
\\
50\end{array}$} & 500 & 1.8 & & 0 & 0 & 0.3 & 1.3 \\
\hline & 333 & 2.0 & & 0 & 0 & 0.5 & 0.6 \\
\hline & 250 & 1.8 & & 0 & 0.1 & 0.5 & 1.6 \\
\hline & 無加用 & 2.2 & & 0 & 0 & 1.4 & 5.0 \\
\hline \multirow{4}{*}{$\begin{array}{c}\text { フルパリ } \\
\text { ネート } \\
\quad 100\end{array}$} & 500 & 2.2 & & 0 & 0 & 0.3 & 1.1 \\
\hline & 333 & 2.5 & & 0 & 0 & 0.3 & 0.9 \\
\hline & 250 & 2.0 & & 0 & 0 & 1.3 & 3.6 \\
\hline & 無加用 & 1.9 & & 0 & 0.1 & 1.3 & 4.0 \\
\hline
\end{tabular}

加用することによって合ピレ郕のミカンハダニに対す る効果を增大させるのはアセフェートに特有な現象であ ることを明らかにするために行った試験の結果が第 2 表 で，供試した有機リン系殺虫骩の中でフルバリネートの 効果を顕著に増大させることができたのはアセフェート のみであった。

加用するアセフェートの濃度別効果を，フェンプロパ トリンとフルバリネートについてみたのが第 3 表で，フ エンプロパトリンではアセフェートの500ppm 250ppm 間に䫓著な差がなかったが、フルバリネートでは 250ppmの場合明らかに効果が劣った。

\section{引用 文 献}

1) 行徳裕 - 磯田隆晴 - 上村道生 (1988) 九病虫研会報 $34: 164$ -186. 2) 古橋嘉一・西野操（1984）関西病虫研会報26:69 (1989年 5 月24日 受領) 